\title{
Biological potency evaluation and physicochemical characterization of unfractionated heparins
}

\author{
Avaliação biológica de potência e caracterização físico-química de heparinas não fracionadas
}

Sérgio L. Dalmora ${ }^{l}$

Ricardo B. Souto ${ }^{2}$

Lucélia M. Silva ${ }^{2}$

Aline D. Lana ${ }^{2}$

Renato Schutkoski

Silvana F. Vaccari ${ }^{2}$

\begin{abstract}
Unfractionated heparins are used clinically as anticoagulants. The biological potency of thirteen samples of raw material and pharmaceutical formulations were assessed utilizing the 5th International Standard of heparin using the sheep plasma coagulation inhibition assay, activated partial thromboplastin time, anti-factor Xa assay, and anti-factor II a assay, resulting in mean potencies of 101.15\%, 96.15\%, 98.15\% and $99.37 \%$, respectively. The samples were also evaluated by the protamine neutralization test giving results within the range of $92-138 \mathrm{IU} / \mathrm{mg}$. The anti-factor II a assay was performed showing reproducibility and significant correlation with the pharmacopoeial assays, thus demonstrating it to be a feasible alternative to the sheep plasma coagulation inhibition assay. Moreover, an analysis by nuclear magnetic resonance and capillary electrophoresis showed some peaks attributable to oversulfated chondroitin sulfate. The results show that batch-to-batch variations and the quality of samples contributed to improvements in the quality control of pharmaceutical products and to assure the safe use and clinical efficacy of this biological medicine. Rev. Bras. Hematol. Hemoter.
\end{abstract}

Key words: Unfractionated heparins; anti-factor Xa; activated partial thromboplastin time; anti-factor IIa; protamine; capillary electrophoresis.

\section{Introdução}

Heparins are heterogeneous mixture of branched glycosaminoglicans extracted from mammalian tissues, most commonly from porcine and bovine mucous. Its molecular weight ranges from 3,000 - 30,000 Daltons, and is composed of polymers of alternating derivates of $\alpha$-D-glucosamine ( $N$-sulfated, $O$ - sulfated, or $N$-acetylated) and uronic acid ( $\alpha$-L-iduronic acid or $\beta$-D-glucuronic acid) joined by 1,4glycosidic linkages forming chains of various lengths. ${ }^{1,2}$

Heparins are widely used as anticoagulant in a number of settings, including kidney dialysis and in initial treatment of venous thrombosis, pulmonary embolism and acute coronary syndrome. ${ }^{3}$
Heparin is an indirect anticoagulant and the bioactivity is largely mediated through its interchange in the plasma cofactor antithrombin III (ATIII), that induces a conformational change in ATIII and so markedly accelerates its ability to inactivate the coagulation enzymes thrombin factor IIa, and factors IXa, Xa, XIa and XIIa. The major anticoagulant effect of heparins is accounted for by a unique pentasacharide present in only one third of heparin molecules with a high affinity binding sequence to ATIII. In addition, heparin increases the rate of the thrombin-heparin cofactor II (HC II) reaction by a second mechanism, although at higher concentrations than those required for the thrombin-ATIII reaction. ${ }^{4-6}$

Recently there has been a marked increase in serious

${ }^{1}$ Professor Titular da Universidade Federal de Santa Maria. Departamento de Farmácia Industrial, Universidade Federal de Santa Maria - RS
${ }^{2}$ Farmacêtico(a). Departamento de Farmácia Industrial, Universidade Federal de Santa Maria, Santa Maria - RS.

Universidade Federal de Santa Maria-RS.

Correspondência: Sérgio Luiz Dalmora

Departamento de Farmácia Industrial - Campus UFSM

97105-900 - Santa Maria-RS - Brasil

E-mail:sdalmora@terra.com.br

Doi: 
adverse events associated with unfractionated heparins therapy. Although heparin therapy is generally well tolerated, patients presented - within several minutes after intravenous infusion of unfractionated heparin angioedema, hypotension, swelling of the larynx and related symptoms, which in some cases ended in death. ${ }^{7}$ The analysis showed potencial biologic link between the presence of over-sulfated chondroitin sulfate (OSCS) in the suspect lots of heparin and the observed clinical adverse events. ${ }^{8,9}$

For the quality control of the pharmaceutical preparations, the in vitro bioassays based on the sheep plasma coagulation inhibition (SPCA) assay, activation of the prothrombim partial time (APTT) and amidolytic antifactor Xa (AXa) are suggested. ${ }^{10-12}$ But, recently the antifactor IIa (AIIa) which is used for the low molecular weight heparin evaluation, has been suggested as possible harmonized alternative to improve the potency assessment replacing the widely used SPCA. ${ }^{10,13}$ Besides the neutralizing properties of protamine sulfate on conventional heparins has been used as safe and effective antidote for controlling excessive bleeding.

At moment, important determinants of anticoagulant activity can be assessed by physico-chemical techniques which are not precise enough to replace the in vitro bioassays as predictors of in vivo behavior. The structural identification has been performed by nuclear magnetic resonance (NMR) and capillary electrophoresis (CE) used also to detect differences in oligosaccharide and polysaccharide components in heparins and to provide data on the content of antithrombin binding sites. ${ }^{14-17}$ Capillary electrophoresis (CE) has been increasingly applied for the analysis of complex mixtures of polysaccharides. The total oligosaccharide compositional analysis of heparins by $\mathrm{CE}$ has the potential of detecting subtle changes in heparin structure that can influence its biological activity. ${ }^{18,19}$

The aim of the present study was perform the characterization and the potency evaluation of unfractionated heparin raw materials and pharmaceutical formulations from different sources, by the in vitro biological assays and physico-chemical methods, demonstrating their quality and establishing correlations which can improve the quality control assuring the safety and the clinical efficacy of the medicinal products.

\section{Materials and Methods}

\section{Reagents and pharmaceutical products}

The 5th international standard for unfractionated heparin containing $2031 \mathrm{IU} /$ vial (5th UHS-WHO 97/578), phospholipid bovine brain (WHO 86/516), and the human antithrombin III were kindly donated by the National Institute for Biological Standards and Control (NIBSC; Herts, UK). Simplastin Excels was purchased from
Biomerieux (Durham, NC, USA). Pharmaceutical products containing heparin sodium at $5000 \mathrm{IU} / \mathrm{mL}$ and raw materials were obtained from the Brazilian market, identified by Arabic numbers from 1 to 13 and used within their shelf-life. Factor Xa from bovine plasma was purchased as "DIAGEN" from Diagnostic Reagents Ltd (Thame, UK) and factor IIa from human plasma was purchased from Sigma (St. Louis, MO). Tris (hydroxymethyl) aminomethane was from Pharmacia Biotech (Uppsala, Sweden), acetic acid and sodium phosphate dibasic were from Merck (Darmstadt, Germany), and the chromogenic substrates S-2765 and S-2238 were from Chromogenix (Milan, Italy).

\section{Sheep Plasma Coagulation Inhibition Assay}

The assay was performed as described elsewhere, ${ }^{10,20,21}$ by independent evaluation of the concentrations of heparin standard and samples that allowed 50 percent coagulation degree of the citrated and recalcified sheep plasma. The extent of clotting in each tube was recorded and used for the statistical analysis. ${ }^{10}$

\section{Activated Partial Thromboplastin Time Assay}

The assay was carried out as described elsewhere. $^{12,13,16}$ Three concentrations at $0.2,0.4$ and $0.8 \mathrm{IU} / \mathrm{mL}$ were selected according to the linear range of the doseresponse curve of the 5th UHS. The assay was performed in duplicate adding $100 \mu \mathrm{L}$ of plasma and $100 \mu \mathrm{L}$ of standard or sample solution of heparin in assay tubes placed in coagulometer at $37^{\circ} \mathrm{C}$ and incubated for $15 \mathrm{~min}$. Then, 100 $\mu \mathrm{L}$ of APTT reagent (Kaolin $4 \mathrm{~g} / \mathrm{L}$ and phospholipid 1/200, equal volumes) were added and the mixture was incubated for $2 \mathrm{~min}$. Finally, $100 \mu \mathrm{L}$ of $25 \mathrm{mM} \mathrm{CaCl} 2$ was added and the clotting time recorded.

\section{Anti-Xa Chromogenic Assay}

The assay was performed as described elsewhere. ${ }^{10,22}$ Five concentrations, in triplicate, at $0.06,0.12,0.18,0.24$, and $0.30 \mathrm{IU} / \mathrm{mL}$ were selected according to the linear range of the dose-response of the 5th UHS. A total of $100 \mu \mathrm{L}$ of antithrombin III solution and $100 \mu \mathrm{L}$ of the appropriate dilution of the substance to be examined or the reference preparation were added to the assay tube, and gently mixed. Then $25 \mu \mathrm{L}$ of that mixture was transferred to the respective well of a 96-well plate, and allowed to equilibrate at $37^{\circ} \mathrm{C}$ (water bath or heating block), and $50 \mu \mathrm{L}$ of bovine factor $\mathrm{Xa}$ solution added. The plate was incubated for exactly $2 \mathrm{~min}$, and then $100 \mu \mathrm{L}$ of chromogenic substrate S-2765 was added. The reaction was stopped after exactly $4 \mathrm{~min}$ by adding 100 $\mu \mathrm{L}$ of $20 \%$ acetic acid solution. The absorbance was measured at $405 \mathrm{~nm}$ in a microplate reader.

\section{Anti-IIa Chromogenic Assay}

The assay was carried out as previously described. ${ }^{11,23}$ Four concentrations at $0.12,0.20,0.28$, and $0.36 \mathrm{IU} / \mathrm{mL}$ were 
selected according to the linear range of the dose-response curve of the 5 th UHS. The assay was performed by using bovine factor IIa solution and chromogenic substrate S2238 changing the procedure described above for the antifactor Xa assay.

\section{Protamine Neutralization Assay}

The assay was adjusted and carried out as described elsewhere. ${ }^{10}$ Ten assay tubes were placed in the coagulometers (H. Amelung Gmbh D-4920 Lemgo, Germany) at $37 \pm 0.2^{\circ} \mathrm{C}$, and added $250 \mu \mathrm{L}$ of plasma. The volume of 50 $\mu \mathrm{L}$ of protamine solution was added in nine of the tubes, keeping the tenth tube as the control. Into the nine remaining tubes graded amounts of the heparins samples were added, selecting the amounts so that the largest did not exceed 60 $\mu \mathrm{L}$, and so that they correspond roughly to a geometric series in which each step was approximately $5 \%$ greater than the next lower. To each tube was added saline to make $450 \mu \mathrm{L}$. Then, $50 \mu \mathrm{L}$ of calcium-thromboplastin solution was added, and the clotting time for each tube was noted in the coagulometers.

\section{Statistical analysis}

Statistical analyses of the assay data were performed as described, ${ }^{24}$ by parallel line methods ( $\left.3 \times 3\right)$, using PLA 1.2 (Stegmann Systemberatung, Rodgau, Germany), with the significance level of $\mathrm{P}=0.05$.

\section{Nuclear magnetic resonance}

The ${ }^{13} \mathrm{C}$ and ${ }^{1} \mathrm{H}$ experiments were performed on a Bruker Avance DRX-400 MHz spectrometer with a $5 \mathrm{~mm}$ inverse probe with Fourier transformer. All data were processed using Bruker's Topspin 1.3 software. Samples were prepared by successive dissolution in deuterium oxide $\left(\mathrm{D}_{2} \mathrm{O} 99.9 \%\right.$, Cambridge Isotope Laboratory), frozen, lyophilized before ${ }^{1} \mathrm{H}$ analyses. ${ }^{1} \mathrm{H}-\mathrm{NMR}(400 \mathrm{MHz}){ }^{13} \mathrm{C}-\mathrm{NMR}(100.6 \mathrm{MHz})$ analyses were performed at $30^{\circ} \mathrm{C}$ in $\mathrm{D}_{2} \mathrm{O}$, chemical shifts being expressed in $\delta$ PPM. The proton chemical shifts were identified according to the literature. ${ }^{15,19}$ Spectral parameters include no less than 8 transient, $90^{\circ}$ pulse width, acquisition time of at least $1 \mathrm{~s}$ time between transients of $20 \mathrm{~s}$ and a spectral window of $4789 \mathrm{~Hz}(12 \mathrm{ppm})$ with the transmitter offset at $5.0 \mathrm{ppm}$, yielding a digital resolution of $0.15 \mathrm{~Hz}$ per point.

\section{Capillary electrophoresis}

All experiments were carried out on a fused-silica capillary with $50 \mu \mathrm{m}$ i.d. and $48.5 \mathrm{~cm}$ of total length (effective length $40 \mathrm{~cm}$ ), thermostatized at $25^{\circ} \mathrm{C}$, and detection at 191 $\mathrm{nm}$ using a PDA detector. The capillary was conditioned by rinsing with $1 \mathrm{M}$ sodium hydroxide for $5 \mathrm{~min}$, followed by water for $5 \mathrm{~min}$, phosphoric acid for $5 \mathrm{~min}$, water for $5 \mathrm{~min}$ and then with running electrolyte solution composed by $60 \mathrm{mM}$ monobasic sodium phosphate, $\mathrm{pH} 3.5$, for $5 \mathrm{~min}$. To achieve high migration time reproducibility between injections, the capillary was conditioned with water ( $5 \mathrm{~min}$ ), and a running electrolyte solution ( $2 \mathrm{~min}$ ). The sample solutions of heparin were diluted in water to obtain a concentration of $2 \mathrm{mg} / \mathrm{mL}$ and were injected using the hydrodynamic injection for 30 seconds at $50 \mathrm{mbar}$, and a constant voltage of $-30 \mathrm{kV}$ (current about $-55 \mu \mathrm{A}$ ) was applied during the analysis. Since electrolysis can change the electroosmotic flow and affect the migration time, efficiency and selectivity, after each three injections the running electrolyte solution was replaced by a fresh solution. ${ }^{18,19}$

\section{Results and discussion}

The structures of the bovine heparins in raw materials were analyzed by ${ }^{13} \mathrm{C}$ and ${ }^{1} \mathrm{H}$ NMR and the typical profile obtained by ${ }^{1} \mathrm{H}$ for the samples 13 and 10 are shown in the Figure $1 \mathrm{~A}$ and $1 \mathrm{~B}$, respectively. The characteristic signals of heparins (Figure 1B) at $\delta 5.40$ show the units of 2-N-sulfoalfa-D-glucosamine $\left(\mathrm{H}-1_{\text {ANS }}\right)$ and 2-N-acetyl- $\alpha$-D-glucosamine $\left(\mathrm{H}-1 \mathrm{~A}_{\mathrm{NAc}}\right)$, and at $\delta 5.23$ units of 2-O-sulfo- $\alpha$-L-iduronic acid $\left(\mathrm{H}-1 \mathrm{I}_{2 \mathrm{~S}}\right)$, and at $2.041 \mathrm{ppm}$ the confirmation of the presence of methyl groups of 2-N-acetyl- $\alpha-D$-glucosamine $\left(\mathrm{H}-1 \mathrm{~A}_{\mathrm{NAc}}\right)$. The sample showed also a signal related to the presence of methyl groups of Dermatan at $2.068 \mathrm{ppm}$, which were confirmed by the signal at $\delta 24.8$ in the ${ }^{13} \mathrm{C}$ spectrum. Besides, the signals detected in the fingerprint region at $\delta 4.98,4.89$ and 2.16 indicated the presence of the over-sulfated chondroitin sulfate in this sample.

Moreover, the samples were also analyzed by the capillary electrophoresis and the typical electropherograms of the samples identified as 13 and 10, demonstrated in Figure $2 \mathrm{~A}$ and $2 \mathrm{~B}$, respectively. The peak identified with the migration time of $2.50 \mathrm{~min}$ (Figure 2B) is attributable to the contamination by OSCS, as previously described, ${ }^{19}$ which can cause unexpected side effects and fail the quality control.

The potency evaluation and the characterization of the same eight commercial batches of unfractionated heparins and five of raw materials from differents sources was performed by the in vitro biological assays recommended for the quality control, establishing comparisons between the procedures and the results found against the specifications that claim potencies between $90 \%-110 \%$ with fiducial intervals within $80 \%-125 \%(\mathrm{P}=0.05) .{ }^{10,20}$

The coagulation degrees obtained in the assays of the samples of raw materials and pharmaceuticals formulations by the SPCA were subjected to statistical analysis, ${ }^{10}$ giving independent potencies within $99.08 \%$ $102.97 \%$ with mean value of $101.15 \%$, and the confidence intervals $(\mathrm{P}=0.95)$ demonstrated in Table 1 .

The same samples were assayed also by the APTT assay and the clotting times obtained were submitted to statistical analysis, giving potencies results between $92.92 \%$ $-98.96 \%$ with the confidence intervals $(\mathrm{P}=0.95)$ shown in 
Table 2. The average of the potencies was $96.15 \%$, which is $5 \%$ lower compared to the SPCA with significant differences $(\mathrm{P}<0.05)$.

The cromogenic AXa assay is based on the coagulation cascade and was performed with the same samples and the absorbance values were subjected to parallel line statistic analysis giving potencies between $95.42 \%-100.77 \%$, with the

\section{A}

B

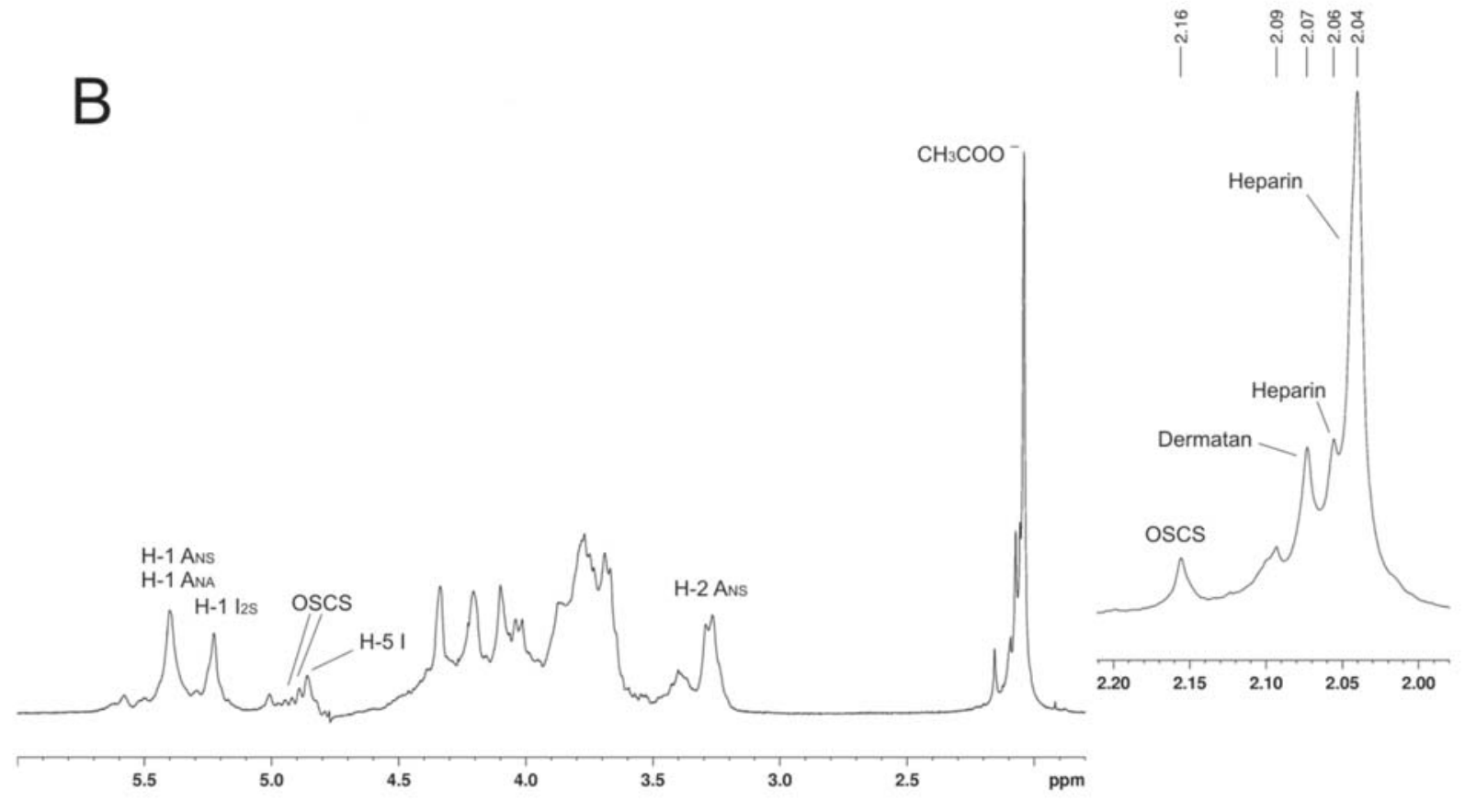

Figure 1. Typical NMR spectra of bovine heparins: $(A)$ raw material and (B) raw material contaminated by over-sulfated chondroitin sulfate

confidence intervals $(\mathrm{P}=0.95)$ shown in Table 3 . The mean potency was $98.15 \%$, which is $3 \%$ lower compared to the SPCA. Compared to the APTT the value was $2 \%$ higher, but with significant correlation as calculated by the Pearson's correlation coefficient $(\mathrm{r}=0.9360)$.

The cromogenic AIIa assay is usually applied for the potency evaluation of the low molecular weight heparins.
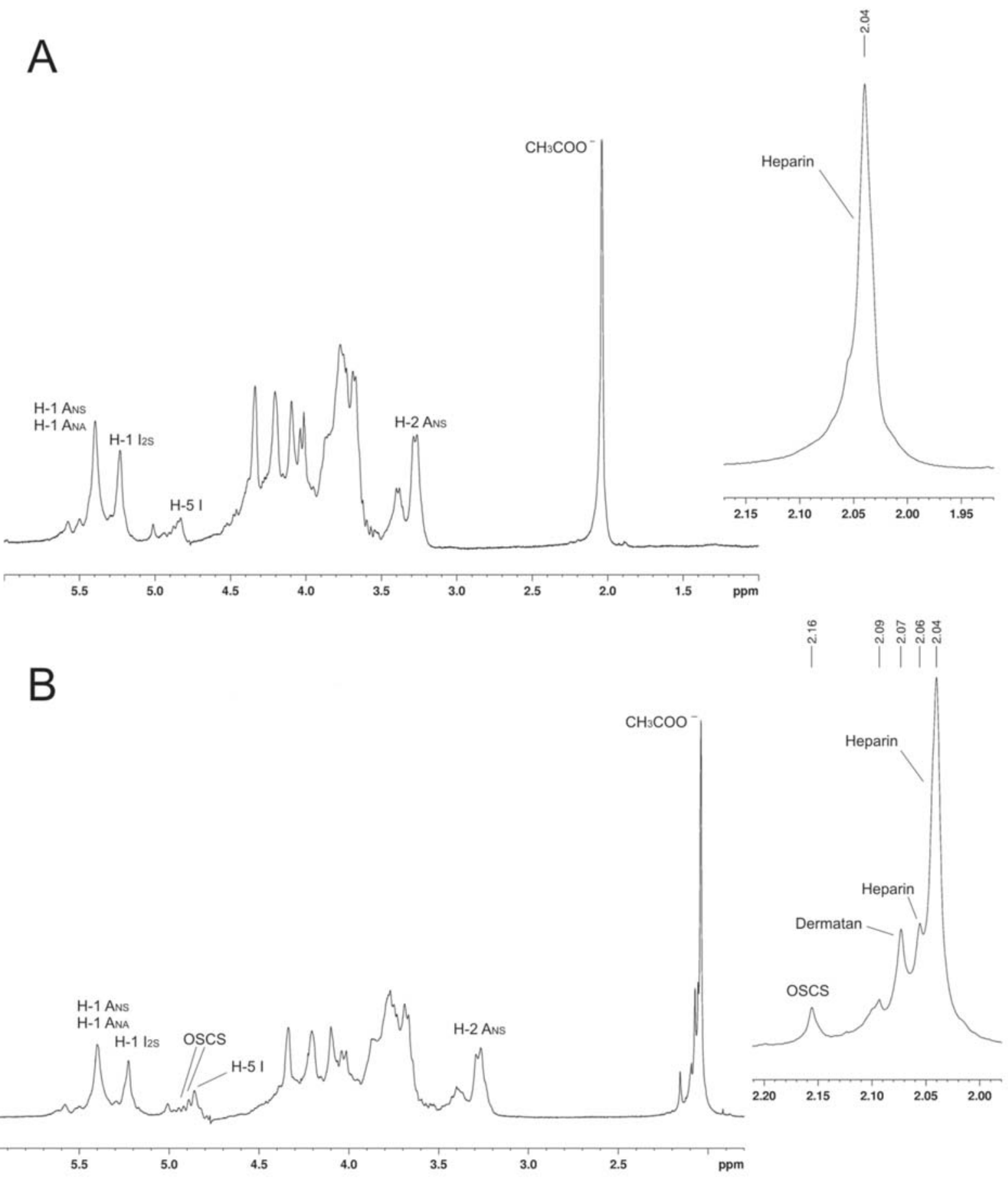

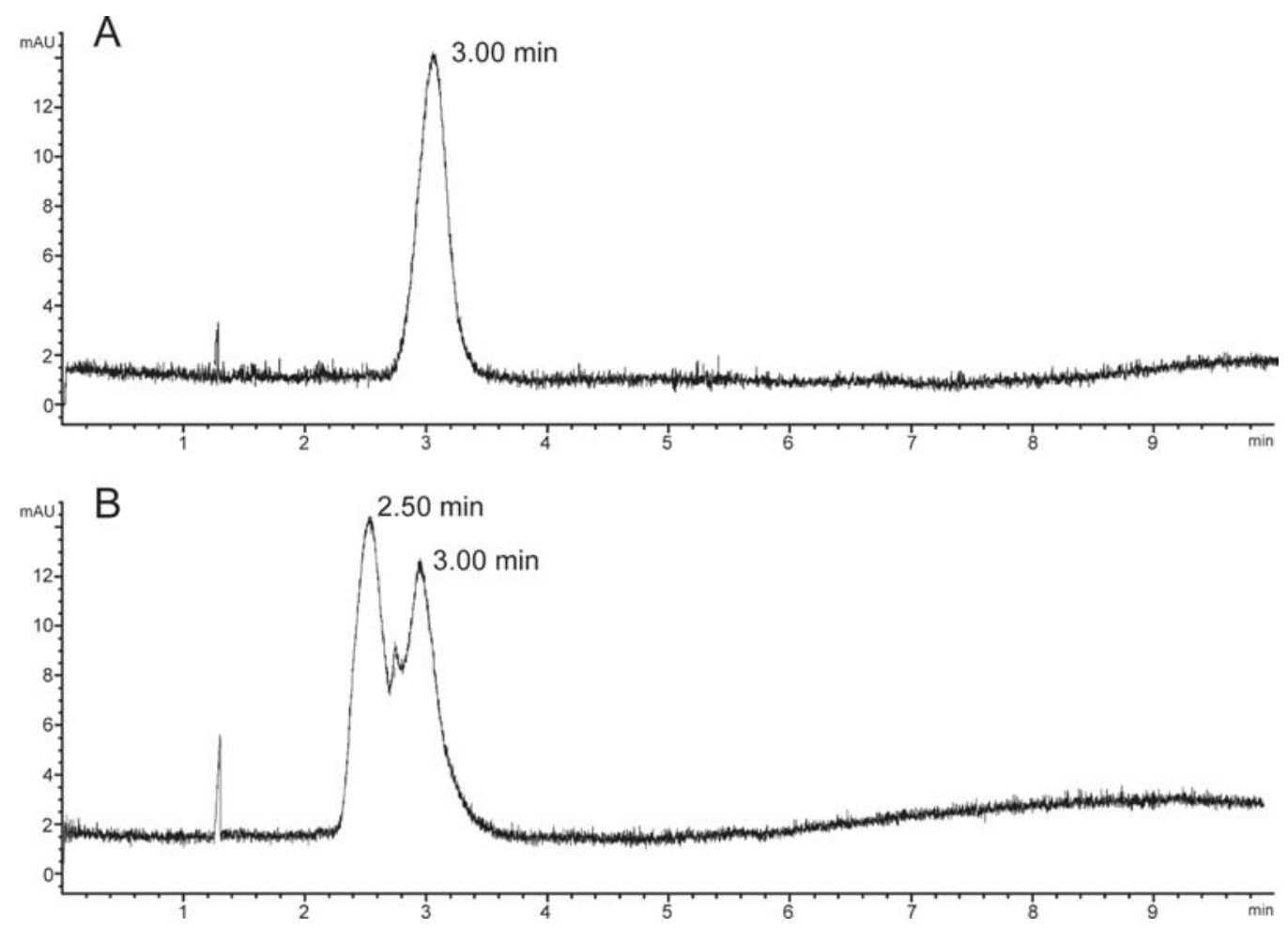

Figure 2. Typical electropherogram of bovine heparins: (A) raw material and (B) raw material contaminated by over-sulfated chondroitin sulfate

Table 1. Potency and confidence intervals assessed for the unfractionated heparin pharmaceutical formulations and raw materials against the 5th international standard for unfractionated heparin by the sheep plasma coagulation inhibition assay

\begin{tabular}{ccccc}
\hline & \multicolumn{3}{c}{ Potency } & $\begin{array}{c}\text { Confidence } \\
\text { Intervals }(P=0.95)\end{array}$ \\
\cline { 2 - 5 } $\begin{array}{c}\text { Sample } \\
\text { assay }\end{array}$ & Stated & \multicolumn{2}{c}{ Found $^{\mathrm{a}}$} & $\%$ \\
\cline { 2 - 5 } & $\mathrm{IU} / \mathrm{mL}$ & $\mathrm{IU} / \mathrm{mL}$ & $\%$ & $97.90-105.10$ \\
\hline 1 & 5000 & 5072 & 101.44 & $96.43-107.81$ \\
3 & 5000 & 5098 & 101.96 & $97.97-104.93$ \\
4 & 5000 & 5070 & 101.39 & $97.89-106.04$ \\
5 & 5000 & 5094 & 101.88 & $97.10-107.94$ \\
6 & 5000 & 5119 & 102.38 & $99.21-106.87$ \\
7 & 5000 & 5149 & 102.97 & $97.98-104.95$ \\
8 & 5000 & 5071 & 101.41 & $93.89-104.56$ \\
$9^{*}$ & 156 & 155.26 & 99.53 & $95.68-103.53$ \\
$10^{*}$ & 156 & 155.28 & 99.54 & $95.67-103.56$ \\
$11^{*}$ & 156 & 156.04 & 100.03 & $96.54-103.64$ \\
$12^{*}$ & 152 & 153.40 & 100.92 & $95.71-106.41$ \\
$13^{*}$ & 154 & 157.66 & 102.38 & $97.10-107.94$ \\
\hline Mean $^{*}$ & & & 101.15 & \\
RSD $^{\mathrm{b}}$ & & & 1.23 & \\
\hline & & & &
\end{tabular}

*Raw material

a Combination of 3 assays

${ }^{\mathrm{b}} \mathrm{RSD}=$ Relative standard deviation
Table 2. Potency and confidence intervals assessed for the unfractionated heparin pharmaceutical formulations and raw materials against the 5 th international standard for unfractionatec heparin by the activated partial thromboplastin time assay

\begin{tabular}{|c|c|c|c|c|}
\hline \multirow[b]{3}{*}{$\begin{array}{c}\text { Sample } \\
\text { assay }\end{array}$} & \multicolumn{3}{|c|}{ Potency } & \multirow{3}{*}{$\begin{array}{c}\text { Confidence } \\
\text { Intervals }(P=0.95) \\
\%\end{array}$} \\
\hline & \multirow{2}{*}{$\begin{array}{l}\text { Stated } \\
\mathrm{IU} / \mathrm{mL}\end{array}$} & \multicolumn{2}{|c|}{ Found $^{a}$} & \\
\hline & & $\mathrm{IU} / \mathrm{mL}$ & $\%$ & \\
\hline 1 & 5000 & 4796 & 96.32 & $91.13-101.96$ \\
\hline 2 & 5000 & 4825 & 96.50 & $93.66-99.57$ \\
\hline 3 & 5000 & 4818 & 98.96 & $94.33-104.48$ \\
\hline 4 & 5000 & 4851 & 96.61 & $91.44-103.34$ \\
\hline 5 & 5000 & 4849 & 95.97 & $90.35-104.24$ \\
\hline 6 & 5000 & 4841 & 95.92 & $93.03-101.19$ \\
\hline 7 & 5000 & 4855 & 97.10 & $90.65-100.79$ \\
\hline 8 & 5000 & 4867 & 96.53 & $93.44-103.21$ \\
\hline $9^{\star}$ & 156 & 147.59 & 95.21 & $90.34-99.77$ \\
\hline $10^{*}$ & 156 & 147.95 & 94.84 & $93.33-96.47$ \\
\hline $11^{\star}$ & 156 & 148.07 & 92.92 & $83.72-99.46$ \\
\hline $12^{*}$ & 152 & 146.08 & 96.11 & $93.77-98.51$ \\
\hline $13^{\star}$ & 154 & 147.11 & 96.93 & $91.02-102.12$ \\
\hline Mean & & & 96.15 & \\
\hline $\mathrm{RSD}^{\mathrm{b}}$ & & & 1.44 & \\
\hline
\end{tabular}

${ }^{*}$ Raw material

a Combination of 3 assays

${ }^{b} \mathrm{RSD}=$ Relative standard deviation 
Recently, has been also suggested as alternative to the SPCA for the potency evaluation of the unfractionated heparins and was performed using the same batches of samples. The absorbances obtained were submitted to parallel line analysis giving potencies between $96.61 \%-101.76 \%$ with the confidence intervals $(\mathrm{P}=0.95)$ demonstrated in Table 4 . The mean potency calculated for the batches tested was $99.37 \%$, which was $1.78 \%$ lower compared to the SPCA. The results were also $3.22 \%$ and $1.22 \%$ higher compared respectively, to the APTT and AXa, but with significant correlation $(\mathrm{P}>0.05)$, following also previously published data. ${ }^{13}$

Protamine sulfate or chloride formulations are clinically available and used for the neutralization of heparins. The test was adjusted and performed for the evaluation of the same samples showing differences in the neutralization rates, mainly for the finished products, which could be related to the quality with influence in the clinical efficacy. As presented in Table 5 the samples 4, 5 and 7 fail due to the low neutralization capacity, out of specification of $100 \mathrm{IU} / \mathrm{mg}$.

A combination of physico-chemical methods and biological assays was applied for the structural identification, characterization and potency evaluation of the same batches of unfactionated heparin raw materials and pharmaceutical formulations. The existing pharmacopoeial assays were

Table 3. Potency and confidence intervals assessed for the unfractionated heparin pharmaceutical formulations and raw materials against the 5th international standard for unfractionated heparin by the anti-factor Xa assay

\begin{tabular}{|c|c|c|c|c|}
\hline \multirow[b]{3}{*}{$\begin{array}{c}\text { Sample } \\
\text { assay }\end{array}$} & \multicolumn{3}{|c|}{ Potency } & \multirow{3}{*}{$\begin{array}{l}\text { Confidence Intervals } \\
\qquad(P=0.95) \\
\%\end{array}$} \\
\hline & \multirow{2}{*}{$\begin{array}{l}\text { Stated } \\
\mathrm{IU} / \mathrm{mL}\end{array}$} & \multicolumn{2}{|c|}{ Found $^{a}$} & \\
\hline & & $\mathrm{IU} / \mathrm{mL}$ & $\%$ & \\
\hline 1 & 5000 & 4946 & 98.91 & 91.72 - 106.67 \\
\hline 2 & 5000 & 4915 & 98.29 & $96.54-100.06$ \\
\hline 3 & 5000 & 5039 & 100.77 & $89.53-113.36$ \\
\hline 4 & 5000 & 4909 & 98.17 & $85.15-103.13$ \\
\hline 5 & 5000 & 4872 & 97.44 & $83.78-113.21$ \\
\hline 6 & 5000 & 4882 & 97.63 & $87.46-108.93$ \\
\hline 7 & 5000 & 4956 & 99.11 & $88.75-110.66$ \\
\hline 8 & 5000 & 4901 & 98.01 & $85.33-112.48$ \\
\hline $9^{*}$ & 156 & 152.72 & 97.90 & $96.95-105.45$ \\
\hline $10^{*}$ & 156 & 152.49 & 97.75 & $92.18-115.13$ \\
\hline $11^{*}$ & 156 & 148.85 & 95.42 & $94.34-112.78$ \\
\hline $12^{*}$ & 152 & 149.05 & 98.06 & $87.57-116.81$ \\
\hline $13^{\star}$ & 154 & 151.70 & 98.51 & $92.91-117.24$ \\
\hline Mean & & & 98.15 & \\
\hline $\mathrm{RSD}^{\mathrm{b}}$ & & & 1.21 & \\
\hline
\end{tabular}

*Raw material

a Combination of 3 assays

${ }^{\mathrm{b}} \mathrm{RSD}=$ Relative standard deviation

\begin{tabular}{|c|c|c|c|c|}
\hline \multirow[b]{3}{*}{$\begin{array}{c}\text { Sample } \\
\text { assay }\end{array}$} & \multicolumn{3}{|c|}{ Potency } & \multirow{3}{*}{$\begin{array}{l}\text { Confidence Intervals } \\
\qquad(P=0.95) \\
\%\end{array}$} \\
\hline & \multirow{2}{*}{$\begin{array}{l}\text { Stated } \\
\mathrm{IU} / \mathrm{mL}\end{array}$} & \multicolumn{2}{|c|}{ Found $^{a}$} & \\
\hline & & $\mathrm{IU} / \mathrm{mL}$ & $\%$ & \\
\hline 1 & 5000 & 4991 & 99.82 & $93.61-109.06$ \\
\hline 2 & 5000 & 5035 & 99.30 & $94.27-104.53$ \\
\hline 3 & 5000 & 5043 & 101.76 & $87.57-108.80$ \\
\hline 4 & 5000 & 5019 & 99.28 & $88.26-110.76$ \\
\hline 5 & 5000 & 5047 & 98.83 & $93.26-104.58$ \\
\hline 6 & 5000 & 4859 & 99.17 & $86.45-113.67$ \\
\hline 7 & 5000 & 4934 & 100.57 & $89.33-111.52$ \\
\hline 8 & 5000 & 4970 & 99.40 & 87.96 - 124.33 \\
\hline $9^{\star}$ & 156 & 151.97 & 99.42 & $93.15-107.23$ \\
\hline $10^{*}$ & 156 & 154.12 & 98.80 & $89.71-116.44$ \\
\hline $11^{*}$ & 156 & 152.27 & 96.61 & $91.64-102.96$ \\
\hline $12^{*}$ & 152 & 150.78 & 99.20 & $97.75-112.19$ \\
\hline $13^{*}$ & 154 & 155.24 & 99.71 & $90.89-108.08$ \\
\hline Mean & & & 99.37 & \\
\hline RSD & & & 1.16 & \\
\hline
\end{tabular}

${ }^{*}$ Raw material

a Combination of 3 assays

${ }^{\mathrm{b}} \mathrm{RSD}=$ Relative standard deviation

Table 5. Units of heparin of pharmaceutical formulations and raw materials neutralized by $1 \mathrm{mg}$ of protamine sulfate evaluated by the neutralization assay

\begin{tabular}{|c|c|}
\hline Sample assay & Heparin Units neutralized \\
\hline 1 & 115.00 \\
\hline 2 & 115.00 \\
\hline 3 & 103.50 \\
\hline 4 & 98.90 \\
\hline 5 & 92.00 \\
\hline 6 & 103.50 \\
\hline 7 & 98.90 \\
\hline 8 & 126.50 \\
\hline $9^{*}$ & 126.50 \\
\hline $10^{\star}$ & 115.00 \\
\hline $11^{\star}$ & 126.50 \\
\hline $12^{*}$ & 138.00 \\
\hline $13^{\star}$ & 115.00 \\
\hline Mean & 113.41 \\
\hline $\mathrm{RSD}^{\mathrm{a}}$ & . \\
\hline
\end{tabular}

${ }^{\star}$ Raw material

${ }^{a} \mathrm{RSD}=$ Relative standard deviation 
performed showing potencies with significant differences for the sheep plasma inhibition assay compared to the APTT and AXa. Moreover, the AIIa was carried out as new alternative under investigation for the quality control, showing also correlation with the AXa and APTT assays. The results obtained show the application of the assays and the importance of the combination of the methods for the quality control of the pharmaceutical products, and to assure the quality, safety and efficacy of the biological medicine.

\section{Resumo}

As heparinas não fracionadas são utilizadas clinicamente como anticoagulantes. A potência biológica de 13 amostras de matériasprimas e produtos farmacêuticos foram avaliadas em relação ao $5^{a}$ Padrão Internacional de heparina pelos ensaios da inibição da coagulação do plasma ovino, tempo de tromboplastina parcial ativada, anti-fator Xa e anti-fator IIa, que forneceram potências médias de 101,15\%, 96,15\%, 98,15\% e 99,37\%, respectivamente. As amostras foram também submetidas ao teste de neutralização pela protamina que apresentou resultados entre 92-138 UI/mg. Demonstrou-se reprodutibilidade e correlação significativa do ensaio do anti-fator II com os farmacopeicos, constituindo-se em alternativa ao ensaio da inibição da coagulação do plasma ovino. Além disso, as análises realizadas por ressonância magnética nuclear e eletroforese capilar mostraram picos correspondentes à condroitina supersulfatada. Os resultados mostraram variações lote-a-lote e a qualidade das amostras contribuindo para aprimorar o controle de qualidade dos produtos farmacêuticos e garantir a segurança e eficácia terapêutica desses produtos biológicos. Rev. Bras. Hematol. Hemoter.

Palavras-chave: Heparinas não fracionadas; anti-fator Xa; tempo de tromboplastina parcial ativada; anti-fator IIa; protamina; eletroforese capilar.

\section{Acknowledgments}

The authors wish to thank CNPq for the support, the Laboratory of Chemistry of Carbohydrates of Federal University of Paraná for the NMR analysis, and the NMR Laboratory of UFSM.

\section{References}

1. Boneu B. Low molecular weight heparins: are they superior to unfractionated heparins to prevent and to treat deep vein thrombosis? Thromb Res. 2000;100(2):V113-20.

2. Verstraete M. Pharmacotherapeutic aspects of unfractionated and low molecular weight heparins. Drugs. 1990;40(4):498-530.

3. Brunton LB, Lazo JS, Parker KL (Eds.), Goodman \& Gilmans the pharmacological basis of therapeutics, 11th ed., McGraw-Hill, New York, 2006.

4. Hirsh J, Dalen JE, Deykin D, Poller L. Heparin: mechanism of action, pharmacokinetics, dosing considerations, monitoring, efficacy, and safety. Chest. 1992;102(4 Suppl):337S-351S.

5. Di Nisio M, Middeldorp S, Büller HR. Direct thrombin inhibitors. N Engl J Med. 2005;353(10):1028-40.
6. Björk I, Lindahl U. Mechanism of the anticoagulant action of heparin. Mol Cell Biochem. 1982;48(3):161-82.

7. Guerrini M, Beccati D, Shriver Z, Naggi A, Viswanathan K, Bisio A, et al. Oversulfated chondroitin sulfate is a contaminant in heparin associated with adverse clinical events. Nat Biotechnol. 2008;26 (6):669-75.

8. Kishimoto TK, Viswanathan K, Ganguly T, Elankumaran S, Smith $\mathrm{S}$, Pelzer K, et al. Contaminated heparin associated with adverse clinical events and activation of the contact system. N Engl J Med. 2008;358(23):2457-67.

9. Zhang Z, Weïwer M, Li B, Kemp MM, Daman TH, Linhardt RJ. Oversulfated chondroitin sulfate: impact of a heparin impurity, associated with adverse clinical events, on low-molecular-weight heparin preparation. J Med Chem. 2008;51(18):5498-501.

10. The United States Pharmacopeia. 31 edition. Rockville: The United States Pharmacopeial Convention, 2008.

11. European Pharmacopoeia. 6th edition. Strasbourg: Council of Europe, 2008.

12. Barrowcliffe TW. Heparin assays and standardization. In: Lane D. A, Lindahl U. (Ed). Heparin. London: Edward Arnold, 1988; 393-415.

13. Vaccari SF, Brum LJR, Masiero SMK, Fronza M, Dalmora SL. Avaliação comparativa da atividade biológica de heparinas nãofracionadas em produtos farmacêuticos. Rev. Bras. Hematol. Hemoter. 2003;25(2):103-10.

14. Ramasamy I, Kennedy J, Tan K. Capillary electrophoresis for characterization of low molecular weight heparins. Lab Hematol. 2003;9(2):64-6.

15. Beyer T, Diehl B, Randel G, Humpfer E, Schäfer H, Spraul M, et al. Quality assessment of unfractionated heparin using $1 \mathrm{H}$ nuclear magnetic resonance spectroscopy. J Pharm Biomed Anal. 2008; 48(1):13-9.

16. British Pharmacopoeia, London: The Stationery Office, 2008.

17. Melo EI, Pereira MS, Cunha RS, Sá MP, Mourão PA. Controle de qualidade das preparações de heparinas disponíveis no Brasil: implicações na cirurgia cardiovascular. Rev Bras Cir Cardiovasc. 2008;23(2):169-74.

18. Patel RP, Narkowicz C, Hutchinson JP, Hilder EF, Jacobson GA. A simple capillary electrophoresis method for the rapid separation and determination of intact low molecular weight and unfractionated heparins. J Pharm Biomed Anal. 2008;46(1):30-5.

19. The United States Pharmacopeial Convention. Revision Bulletin. Rockville: June 18, 2008.

20. Farmacopéia Brasileira. 4 edição. São Paulo: Atheneu, 1988.

.21. Dalmora SL, Assaf GS, Dalmora ME, Vaucher LC, Vaccari SF. Determinação da atividade anticoagulante da heparina. Rev Hosp Clin Fac Med Sao Paulo. 1991;46(2):59-62.

22. Dalmora SL, Júnior LB, Schmidt CA, Vaccari SF, Oliveira PR, Codevilla CF. Validation of the anti-factor Xa assay for the potency assessment of enoxaparin in pharmaceutical formulations. J AOAC Int. 2004;87(6):1305-08.

23. Dalmora SL, Junior LB, Vaccari SF, Fronza M, Renato de Oliveira P, Rolim CM. Validation of the anti-factor IIa assay and potency assessment of enoxaparin in pharmaceutical formulations. Farmaco. 2005;60(3):225-9.

24. Finney DJ, Statistical Methods in Biological Assay, Charle Griffin, London UK. 1978.

Avaliação: Editor e dois revisores externos

Conflito de interesse: sem conflito de interesse

Recebido: 28/11/2008

Aceito após modificações: 13/04/2009 